\title{
Further results in search for transuranium elements in effluents discharged to air from nuclear power plants
}

\author{
Z. Hölgye • E. Schlesingerová
}

Received: 26 July 2010/Published online: 27 August 2010

(C) The Author(s) 2010. This article is published with open access at Springerlink.com

\begin{abstract}
In this work we present data on transuranium nuclides ${ }^{238} \mathrm{Pu},{ }^{239,240} \mathrm{Pu},{ }^{241} \mathrm{Am},{ }^{242} \mathrm{Cm}$ and ${ }^{244} \mathrm{Cm}$ in effluents discharged to air (activity concentrations and annually discharged activities of individual radionuclides) from 7 stacks in 2004-2009. In the effluents discharged to air from one stack low activities of transuranium nuclides were observed throughout the studied period. Transuranium nuclides had been discharged to air from this stack also in previous years since 1996 when defect in the cladding of a fuel element and consequent contamination of the primary circuit occurred. In the effluents discharged to air from another stack transuranium nuclides were observed only in some monitoring periods of studied years. We could not prove the presence of transuranium nuclides in the effluents of the other stacks up to 2006. The transuranium nuclides in discharged effluents were registered in the second half-year of 2006. In 2007-2008 especially low activities of ${ }^{241} \mathrm{Am}$ were found in these effluents.
\end{abstract}

Keywords Transuranium elements .

Nuclear power plants · Air pollution

\section{Introduction}

Even under normal operation of nuclear power plants (NPPs) discharges of radioactive substances into the atmosphere take place. Considerable attention is given to monitoring of radioactive noble gases, iodine, ${ }^{14} \mathrm{C}$, fission

Z. Hölgye $(\bowtie) \cdot$ E. Schlesingerová

National Radiation Protection Institute, Bartoškova 28,

14000 Prague, Czech Republic

e-mail: zoltan.holgye@suro.cz and activation products in particulate form in airborne effluents. The annual discharged activities of these radionuclides have been reported by individual NPP [1]. On the other hand, there is little information given on the monitoring of the release of biologically important ${ }^{239,240} \mathrm{Pu}$, ${ }^{238} \mathrm{Pu},{ }^{241} \mathrm{Am}$, and other transuranium nuclides (TRU) from NNPs under normal operation conditions [2].

Monitoring of TRU in effluents discharged to air from NPPs started in our institute in 1985. The main objective was to obtain discharge data on TRU for each nuclear power plant operated in the Czech Republic and Slovak Republic. Up to 2003 we had searched for TRU in effluents discharged to air from five stacks (stacks 1 and 2 of the former V1 and V2, NPP Jaslovské Bohunice, stacks 3 and 4 , of the former V3 and V4, NPP Dukovany and stack 5 of NPP Temelin). At four of these stacks (stacks 1-4) the effluents come from the main production building (with two pressurized water reactors of $440 \mathrm{MW}_{\mathrm{e}}$ power of each reactor) and from the auxiliary service building for the primary system. At stack 5 the effluents come from the main production building with one pressurized water reactor of $1,000 \mathrm{MW}_{\mathrm{e}}$ power. The results obtained were from time to time published and observations made during all the study are summarized in the previous paper [2]. They are: (1) ${ }^{238} \mathrm{Pu},{ }^{239,240} \mathrm{Pu},{ }^{241} \mathrm{Am},{ }^{242} \mathrm{Cm}$ and ${ }^{244} \mathrm{Cm}$ can be present in effluents discharged to air. Their activity concentrations and discharged activities from individual stacks, however, vary in wide range. The presence of TRU in effluents from the stack 5 was not proved at all and their activities in effluents from stacks 2 and 4 were either lower than their limits of detection or only slightly exceeded these limits in some monitoring periods. On the other hand, during all the nine years of study measurable activities of TRU were found in the effluents discharged to air from stack 1 and from stack 3 since the third quarter of 1996 as a 
result of a defect in the fuel cladding. At the stack 3 further increases of TRU activities in effluents occurred in the third quarter of 1999 and the third quarter of 2003.

(2) Two phases can be distinguished in the time course of TRU discharge: the first phase represents the first quarter when the increase begins and the second phase represents a further time period with lower discharges. The second phase can last many years. In all the three events at the stack 3 the activity of ${ }^{242} \mathrm{Cm}$ reached the highest value in TRU mixtures in the first phase of the discharge. Nevertheless several other substantially lower increases of TRU discharge with maximum ${ }^{242} \mathrm{Cm}$ content were also registered during the study. Those however lasted for one or two following quarters only.

(3) There exist definite activity ratios of TRU in effluents discharged to air. So activity ratio of ${ }^{238} \mathrm{Pu} /{ }^{239,240} \mathrm{Pu}$ in effluents from the stack 1 was approximately 1.0 during all the 9 years' study. The activity ratios in effluents are given by the ratio of these radionuclides in fuel from which the contamination has originated. We calculated (for definite conditions) the activity ratios of ${ }^{238} \mathrm{Pu} /{ }^{239,240} \mathrm{Pu}$, ${ }^{241} \mathrm{Am} /{ }^{239,240} \mathrm{Pu},{ }^{242} \mathrm{Cm} /{ }^{239,240} \mathrm{Pu}$ and ${ }^{244} \mathrm{Cm} /{ }^{239,240} \mathrm{Pu}$ in fuel for different burn-up values.

(4) TRU discharged to air from the studied stacks contribute very little to further contamination of the environment. For example, the largest annual discharge of ${ }^{239,240} \mathrm{Pu}, 66 \mathrm{kBq}$ from the stack 1 was equivalent to the activity of these radionuclides from atmospheric nuclear tests fallout in top soil for an area $1,100 \mathrm{~m}^{2}$ in our geographic position.

Since 2004 the search for TRU in effluents discharged to air has been extended to further stacks in NPP Temelín. The aim of this paper is to present TRU measurement results obtained in 2004-2009.

\section{Experimental}

Seven stacks were studied in 2004-2009. Two of them (stacks 3 and 4) belong to NPP Dukovany and five (stacks 5-9) to NPP Temelin. At the stack 7 the effluents come (similarly to stack 5) from the main production building with one pressurized water reactor of $1,000 \mathrm{MW}_{\mathrm{e}}$ power. At stacks 6 and 8 the effluents come also from the main production buildings and they are released mainly during shut-down periods. Stack 9 discharges effluents from the auxiliary service building for the primary system.

Aerosol particles were collected (by the NPP staff) using large volume samplers installed in the stacks above the NPP air filtration system. Air filters FPM-1530 made from organic fibres were used during 2004-2009. Filters for collection of aerosol particles were mostly exposed for one week. After gamma spectrometry a part of each exposed filter was cut off and thus obtained portions were put together to yield quarterly samples in 2004-2005, while since 2006, half-year samples have been prepared. TRU in the air filter samples were determined using radiochemical separation and alpha spectrometry as described in our previous paper [2].

\section{Results and discussion}

In Table 1 the annual discharged activities of TRU from the studied stacks in 2004-2009 are presented. As can be seen the annual discharged activities of ${ }^{238} \mathrm{Pu},{ }^{239,240} \mathrm{Pu}$, ${ }^{241} \mathrm{Am},{ }^{242} \mathrm{Cm}$ and ${ }^{244} \mathrm{Cm}$ from the stack 3 varied in the range $960-1800,320-630,760-1600,<320-820$ and 720-3500 Bq, respectively. Similar values for annual discharge were obtained in 2001 and 2002 [2]. There is no evidence for a decrease of the discharged activities within the time period from 2004 to 2009 . For example the discharge of ${ }^{238} \mathrm{Pu}$ in $2004(670 \mathrm{~Bq})$ is lower than the discharge in $2006(950 \mathrm{~Bq})$ and 2008 (890 Bq). Similarly, the ${ }^{239,240} \mathrm{Pu}$ discharge in $2004(390 \mathrm{~Bq})$ is lower than that in 2006 and in 2008 (450 Bq).

We did not find TRU in effluents discharged to air from the stack 4 in the most of monitoring periods before 2004 . During 2004-2009, TRU were sometimes measurable in discharged effluents from this stack (at the level similar to those for the stack 3), sometimes not (Table 1). We cannot give reasonable explanation for this finding.

TRU activities in effluents discharged to air from the stacks 5-9 were mostly either lower than the detection limit or only slightly exceeded this limit in 2004-2009. There are however, two exceptions: (1) ${ }^{241} \mathrm{Am}$ appeared in discharged effluents from these stacks in 2006. Presence of ${ }^{241} \mathrm{Am}$ in air filters samples was revealed by gamma spectrometry measurements. (2) Besides ${ }^{241} \mathrm{Am}$, other low activity TRU appeared especially in the stack 8 in 2006. In Table 2, activity concentrations of TRU in effluents discharged to air and discharged TRU activities from the stacks 5-9 in the first and the second half-year of 2006 are presented. It is obvious from Table 2 that although in the first half-year TRU were not measurable in effluents in the second half-year TRU appeared in effluents from these stacks, with the maximum content of ${ }^{241} \mathrm{Am}$. Maximum concentration of ${ }^{241} \mathrm{Am} 520 \pm 23 \mu \mathrm{Bq} \cdot \mathrm{m}^{-3}$ was found in effluents from the stack 8 . Maximum discharged activity of ${ }^{241} \mathrm{Am}$ amounted to $87000 \mathrm{~Bq}$. At the stack 8, well measurable activities of ${ }^{242} \mathrm{Cm},{ }^{244} \mathrm{Cm}$ and plutonium nuclides were also found in the effluents discharged to air. Discharged activities of ${ }^{241} \mathrm{Am}$ and other TRU from the stacks 5-9 significantly decreased in further years (Table 1). 
Table 1 Annual discharged activities of transuranium nuclides from individual stacks

\begin{tabular}{|c|c|c|c|c|c|c|}
\hline \multirow[t]{2}{*}{ Stack } & \multirow[t]{2}{*}{ Year } & \multicolumn{5}{|c|}{ Annual discharged activities (Bq) } \\
\hline & & ${ }^{238} \mathrm{Pu}$ & ${ }^{239,240} \mathrm{Pu}$ & ${ }^{241} \mathrm{Am}$ & ${ }^{242} \mathrm{Cm}$ & ${ }^{244} \mathrm{Cm}$ \\
\hline \multirow[t]{6}{*}{3} & 2004 & 960 & 390 & 970 & 810 & 1,500 \\
\hline & 2005 & 1,200 & 590 & 910 & $>630<700$ & 1,500 \\
\hline & 2006 & 950 & 450 & 900 & 370 & 1,100 \\
\hline & 2007 & 1,800 & 630 & 1,600 & 820 & 3,500 \\
\hline & 2008 & 890 & 450 & 800 & 450 & 840 \\
\hline & 2009 & 670 & 320 & 780 & $>280<320$ & 720 \\
\hline \multirow[t]{6}{*}{4} & 2004 & $<110$ & $>100<170$ & $>4,000<4,100$ & $<220$ & $>3,300<3,400$ \\
\hline & 2005 & $>130<190$ & $>90<160$ & $>120<210$ & $>150<300$ & $>80<170$ \\
\hline & 2006 & $>780<800$ & $>72<90$ & $>150<170$ & $<38$ & $>40<61$ \\
\hline & 2007 & 63 & 45 & 64 & $<27$ & $>38<53$ \\
\hline & 2008 & 1,500 & 670 & 1,300 & $<70$ & 590 \\
\hline & 2009 & $>42<67$ & $>130<150$ & 110 & $<60$ & $<32$ \\
\hline \multirow[t]{6}{*}{5} & 2004 & $<9$ & $<10$ & $<20$ & $<19$ & $<8$ \\
\hline & 2005 & & & $>45<71$ & $<53$ & $<17$ \\
\hline & 2006 & $<6$ & $<6$ & 1600 & $>17<29$ & $<5$ \\
\hline & 2007 & $>12<15$ & 45 & 170 & $<11$ & $<6$ \\
\hline & 2008 & $>24<27$ & $>8<11$ & 110 & $<23$ & $<5$ \\
\hline & 2009 & $<5$ & 15 & $>2<4$ & $<5$ & $<3$ \\
\hline \multirow[t]{6}{*}{6} & 2004 & $<24$ & 80 & $<31<63$ & $>400<440$ & $<16$ \\
\hline & 2005 & & & $<110<190$ & $<97$ & $<30$ \\
\hline & 2006 & $<23$ & $<10$ & 86 & $>86<100$ & $<12$ \\
\hline & 2007 & $>6<8$ & $<7$ & 140 & 51 & 4 \\
\hline & 2008 & $<14$ & $<10$ & $>23<37$ & $>110<130$ & $<13$ \\
\hline & 2009 & $<3$ & 90 & 9 & $<5$ & $<3$ \\
\hline \multirow[t]{6}{*}{7} & 2004 & $<29$ & $<32$ & $<29$ & $<27$ & $<9$ \\
\hline & 2005 & & $<25$ & $>18<34$ & $<70$ & $<18$ \\
\hline & 2006 & $<7$ & $<7$ & 52,000 & $<33$ & $<7$ \\
\hline & 2007 & $<4$ & $<3$ & 100 & $<3$ & $<2$ \\
\hline & 2008 & $<9$ & $<9$ & 38 & $<19$ & $<8$ \\
\hline & 2009 & 17 & $<3$ & $>2<10$ & $<11$ & $<4$ \\
\hline \multirow[t]{6}{*}{8} & 2004 & $<35$ & $>32<59$ & $>18<38$ & $<45$ & $<16$ \\
\hline & 2005 & & & & & \\
\hline & 2006 & 170 & 83 & 87,000 & 2,300 & 90 \\
\hline & 2007 & 9 & 54 & 45 & 690 & 43 \\
\hline & 2008 & 26 & $<3$ & 14 & 110 & 10 \\
\hline & 2009 & $<21$ & $<11$ & 150 & 55 & $<9$ \\
\hline \multirow[t]{6}{*}{9} & 2004 & $<230$ & $<250$ & $<100$ & $<130$ & $<44$ \\
\hline & 2005 & & & $<58$ & $<130$ & $<27$ \\
\hline & 2006 & $>150<160$ & $>70<90$ & 44,000 & $>140<180$ & $<31$ \\
\hline & 2007 & $>62<86$ & 110 & 1,800 & $>180<250$ & $<46$ \\
\hline & 2008 & $<27$ & $>330<340$ & 160 & $<71$ & $<37$ \\
\hline & 2009 & $<28$ & $<22$ & 34 & $<20$ & $<8$ \\
\hline
\end{tabular}

In our previous work we found that radionuclide composition of TRU in discharged effluents is not random, but it is connected with burn-up values of fuel particles from which the contamination originated [2]. The results of present work also confirm this finding. In Table 3 the activity ratios of TRU in effluents discharged to air from 


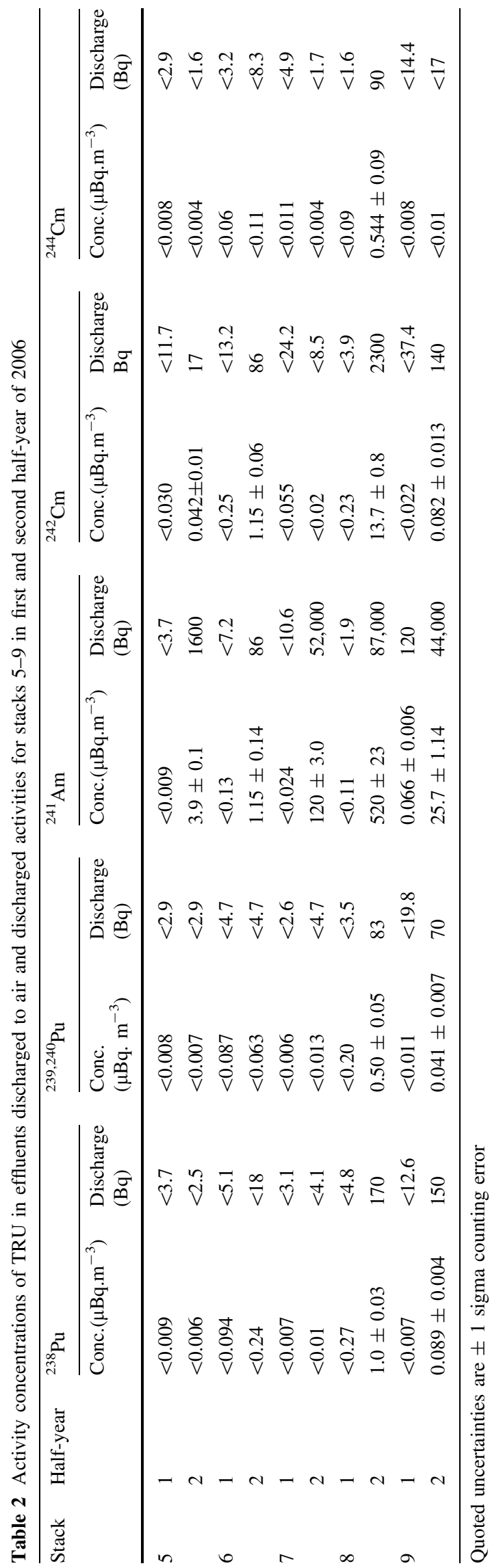

the stack 3 in studied years and in second half-year of 2006 from the stack 8 are presented. It can be seen that the activity ratios of ${ }^{238} \mathrm{Pu} /{ }^{239,240} \mathrm{Pu}$ in effluents from stack 3 in 2004-2009 are close to value 2 . Similar values for activity ratios of ${ }^{238} \mathrm{Pu} /{ }^{239,240} \mathrm{Pu}$ in effluents from this stack were found since the $3^{\text {rd }}$ quarter of 1996 up to the second quarter of 1999 and in 2002-2003 [2]. The obtained ratios of ${ }^{241} \mathrm{Am} /{ }^{239,240} \mathrm{Pu}$ and ${ }^{244} \mathrm{Cm} /{ }^{239,240} \mathrm{Pu}$ in the studied years (Table 3 ) are similar to those found since $3^{\text {rd }}$ quarter of 1999 up to 2003 [2].

Activity ratios of ${ }^{238} \mathrm{Pu} /{ }^{239,240} \mathrm{Pu},{ }^{241} \mathrm{Am} /{ }^{239,240} \mathrm{Pu}$, ${ }^{242} \mathrm{Cm} /{ }^{239,240} \mathrm{Pu}$ and ${ }^{244} \mathrm{Cm} /{ }^{239,240} \mathrm{Pu}$ in the effluents from the stack 8 in the second half-year of 2006 are 2.0, 1048, 27.7, and 1.1, respectively (Table 3). Using relations between the calculated activity ratios of TRU and burn-up values/2/for activity ratios of ${ }^{238} \mathrm{Pu} /{ }^{239,240} \mathrm{Pu}=2.0$ the corresponding burn-up is $27 \mathrm{GWd} / \mathrm{tU}$. For this burn-up value the calculated activity ratios (using the relation between activity ratios and burn-up values/2/) of ${ }^{241} \mathrm{Am} /{ }^{239,240} \mathrm{Pu},{ }^{242} \mathrm{Cm} /{ }^{239,240} \mathrm{Pu}$ and ${ }^{244} \mathrm{Cm} /{ }^{239,240} \mathrm{Pu}$ are $0.14,32$, and 1.2 , respectively. It can be seen that in the case of ${ }^{244} \mathrm{Cm} /{ }^{239,240} \mathrm{Pu}$ ratios the measured (1.1, Table 3) and calculated values (1.2) are close, in the case of ${ }^{242} \mathrm{Cm} /{ }^{239,240} \mathrm{Pu}$ ratio the measured (27.7) and calculated (32) values are similar, in the case of ${ }^{241} \mathrm{Am} /{ }^{239,240} \mathrm{Pu}$ ratios, however, the measured value $(1,048)$ considerably exceeds the calculated value (0.14). For activity ratio ${ }^{241} \mathrm{Am} /{ }^{239,240} \mathrm{Pu}=0.14$, in the case of $83 \mathrm{~Bq}{ }^{239,240} \mathrm{Pu}$ discharge (data for stack 8 in the second half year, 2006, Table 2) the corresponding ${ }^{241} \mathrm{Am}$ discharge should be 11.6 Bq. The measured ${ }^{241} \mathrm{Am}$ discharge is $87000 \mathrm{~Bq}$. We cannot explain relatively high ${ }^{241} \mathrm{Am}$ discharge from the stack 8 from fuel-cycle. An explanation is even more difficult for the stack seven because in effluents discharged to air from this stack no ${ }^{238} \mathrm{Pu},{ }^{239,240} \mathrm{Pu}$ and ${ }^{242} \mathrm{Cm}$ were found.

To get an idea of how the studied stacks contributed to further contamination of the environment, we compared the annual discharged activities with the activities of an area of soil surface contaminated by fallout from atmospheric nuclear tests (in the case of ${ }^{238} \mathrm{Pu}$ also from SNAP-9A satellite burn-up). Taking into account the fact that at latitudes $40^{\circ}$ to $50^{\circ} \mathrm{N}$ the fallout of ${ }^{239,240} \mathrm{Pu},{ }^{238} \mathrm{Pu}$ and ${ }^{241} \mathrm{Am}$ till 1978 amounted to $58,1.5$ and 25 Bq. ${ }^{-2}$,respectively [3], the largest annual discharge of ${ }^{239,240} \mathrm{Pu} 670 \mathrm{~Bq}$ in 2004-2009 (stack 4 in 2008) is equivalent to the fallout of these radionuclides on an area of $11.6 \mathrm{~m}^{2}$,in the case of ${ }^{238} \mathrm{Pu}$ the equivalent area (maximum discharge $1,800 \mathrm{~Bq}$, stack 3 in 2007) is $1,200 \mathrm{~m}^{2}$ and in the case of ${ }^{241} \mathrm{Am}$ (maximum discharge $87000 \mathrm{~Bq}$, stack 8, 2006) this area is $3,480 \mathrm{~m}^{2}$. It is evident that even the stacks with the largest annual discharges contribute to further contamination of the environment only to a very small degree. 
Table 3 Activity ratios of TRU in effluents discharged to air for stacks 3 and 8

\begin{tabular}{llllll}
\hline Stack & Year & \multicolumn{4}{l}{ Activity ratio } \\
\cline { 3 - 6 } & & ${ }^{238} \mathrm{Pu} /{ }^{239,240} \mathrm{Pu}$ & ${ }^{241} \mathrm{Am} /{ }^{239,240} \mathrm{Pu}$ & ${ }^{242} \mathrm{Cm} /{ }^{239,240} \mathrm{Pu}$ & ${ }^{244} \mathrm{Cm} /{ }^{239,240} \mathrm{Pu}$ \\
\hline 3 & 2004 & 2.5 & 2.5 & 2.1 & 3.9 \\
& 2005 & 2.0 & 1.5 & 1.1 & 2.5 \\
& 2006 & 2.1 & 2.0 & 0.8 & 2.4 \\
& 2007 & 2.9 & 2.5 & 1.3 & 5.5 \\
& 2008 & 2.0 & 1.8 & 1.0 & 1.9 \\
& 2009 & 2.1 & 2.4 & 0.9 & 2.3 \\
& 2006 & 2.0 & 1048 & 27.7 & 1.1 \\
\hline
\end{tabular}

Acknowledgments The authors would like to thank Mrs M. Ejemová and V. Pešková for technical assistance. We would like also to express many thanks to Mrs V. Bečková for her support and help at preparing this article.

Open Access This article is distributed under the terms of the Creative Commons Attribution Noncommercial License which permits any noncommercial use, distribution, and reproduction in any medium, provided the original author(s) and source are credited.

\section{References}

1. United National Scientific Committee on the Effect of Atomic Radiation (1988) Sources, effects and risk of ionizing radiation. United Nations, New York

2. Hölgye Z, Filgas R (2006) Health Phys 90:328

3. United Nation Scientific Committee on the Effect of Atomic Radiation (1982) Ionizing radiation: sources and biological effects. United Nations, New York 